\title{
Media Belajar Big Book dalam Mengembangkan Kemampuan Berbahasa Reseptif Anak Usia Dini
}

\author{
Dewi Fitriani ${ }^{{ }_{1}}$, Heliati Fajriah ${ }^{2}$, Wirda Rahmita ${ }^{3}$ \\ Pendidikan Islam AnakUsia Dini, Universitas Islam Negeri Ar-Raniry, Banda Aceh ${ }^{12}$ \\ Taman Kanak-kanak Dharma Wanita, Teunom ${ }^{3}$ \\ DOI: $\underline{10.31004 / \text { obsesi.v4i1.197 }}$
}

\begin{abstract}
Abstrak
Menurunnya kemampuan berbahasa reseptif pada anak usia dini menimbulkan kekhawatiran berimbas pada perkembangan kemampuan bahasa ekspresif anak. Kemampuan bahasa reseptif inilah yang menjadi dasar pada timbulnya kemampuan ekspresif anak usia dini. Penelitian ini bertujuan untuk mengetahui perkembangan berbahasa reseptif pada anak usia dini dengan menggunakan big book sebagai media pembelajaran. Penelitian ini dilaksanakan di PAUD Ibnu Sina dengan jumlah subjek penelitian sebanyak delapan orang anak berusia 5-6 tahun. Jenis penelitian ini adalah Penelitian Tindakan Kelas (PTK) yang dilaksanakan dalam dua siklus. Instrumen yang digunakan berupa lembar observasi kemampuan berbahasa reseptif anak. Hasil penelitian menunjukkan perkembangan kemampuan berbahasa reseptip anak yang cukup signifikan selama dua siklus. Hasil belajar anak dengan media big book berhasil mencapai persentase yang lebih tinggi pada perkembangan kemampuan berbahasa anak sebesar $87,5 \%$.
\end{abstract}

Kata Kunci: kemampuan bahasa reseptif; media big book; anak usia dini.

\begin{abstract}
The decline in receptive language skills in early childhood has caused concern because it impacts on the development of children's expressive language skills. This receptive language skill is the basis for the emergence of early childhood expressive abilities. This study aims to determine the development of receptive language in early childhood using big book as a learning medium. This research was conducted at PAUD Ibnu Sina with a total of eight research subjects for children aged 5-6 years. This research type is a Classroom Action Research (CAR) study which is carried out in two cycles. The instrument used was a receptive language ability observation sheet for children. The results showed that the development of children's receptive language skills was quite significant during the two cycles. Children's learning outcomes with the media big book managed to achieve a higher percentage of the development of children's language skills by $87,5 \%$.
\end{abstract}

Keywords: receptive language skill; big book media; young children.

Copyright (c) 2019 Dewi Fitriani,Heliati Fajriah,Wirda Rahmita

$\triangle$ Corresponding author:

Email Address : fitrianide@gmail.com (Banda Aceh, Aceh)

Received 12 June 2019, Accepted 28 September 2019, Published 18 November 2019 


\section{PENDAHULUAN}

Pergeseran gaya interaksi sosial diera revolusi 4.0 ini yang serba melalui gadget, telah mengakibatkan rendahnya kemampuan berbahasa Anak Usia Dini (AUD). Pergeseran ini mengakibatkan semakin minimnya interaksi sosial antar sesama yang berimbas pada menurunnya kemampuan berbahasa reseptif pada AUD. Dapat kita dapati AUD jenjang usia 5-6 tahun yang seharusnya sudah mampu menguasai 8000 kosakata sebagaimana yang dikatakan oleh (Dhieni et al 2014), ternyata tidak mampu memenuhi standar minimal nasional sebagaimana yang tercantum didalam Peraturan Menteri Pendidikan dan Kebudayaan (Permendikbud) No 137 Tahun 2014 tentang Standar Tingkat Pencapaian Perkembangan Anak (STPPA) yang berlaku untuk seluruh Indonesia (Permendikbud 2014).

Kemampuan berbahasa AUD dalam STPPA dibagi ke dalam tiga (3) kategori, yaitu: memahami bahasa; mengungkapkan bahasa; dan keaksaraan. Dan kategori memahami bahasa masuk kedalam kemampuan bahasa reseptif anak. Kemampuan berbahasa anak pada umumnya dibedakan atas kemampuan bahasa reseptif (mendengar dan memahami) dan kemampuan ekspresif (berbicara) (Khairin 2012). Kemampuan bahasa khususnya kemampuan bahasa reseptif (memahami) anak menurut Sandra Levey adalah keterampilan memahami yang meliputi keterampilan anak dalam memahami aturan guru di dalam kelas, perintah, dan penjelasan (Adini 2016). Di samping itu, keterampilan bahasa reseptif yang baik memungkinkan anak untuk memahami kata-kata, kalimat, cerita dan peraturan. Permendikbud No 137 Tahun 2014 dalam lampiran I mencantumkan beberapa poin lingkup perkembangan memahami bahasa anak yaitu: (1) memahami beberapa perintah secara bersamaan; (2) mengulang kalimat yang lebih kompleks; (3) memahami aturan dalam suatu permainan; dan (4) senang dan menghargai bacaan (Permendikbud 2014).

Bromley mengatakan bahwa anak yang terlibat aktif dalam menyimak juga aktif dalam mengonstruksikan arti informasi yang diberikan. Mereka memonitor pemahaman mereka akan informasi yang diperoleh dengan berbagai cara, mengasosiasikan informasi baru dengan informasi yang telah mereka terima sebelumnya, menanyakan tentang ketepatan informasi yang mereka peroleh, dan mengulang maupun menanyakan informasi yang telah diberikan dengan menggunakan kata-kata mereka sendiri (Dhieni et al 2014) Maka akan sering kita dapati bahwa kecenderungan anak yang sering bertanya merupakan anak yang memahami informasi yang mereka terima sebagai bentuk proses memahami ataupun mengasosiasikan informasi baru dengan pengalaman terdahulu mereka.

Sandra Levey dalam (Adini 2016) mengatakan bahwa kemampuan memahami juga meliputi keterampilan anak dalam memahami aturan guru di dalam kelas, perintah, dan penjelasan. Di samping itu, keterampilan bahasa reseptif yang baik memungkinkan anak untuk memahami kata-kata, kalimat, cerita dan peraturan. Hal itu semua tidak terlepas dari fungsi bahasa sebagaimana yang disebutkan oleh Depdiknas dan dipraktekkan anak dalam berbahasa, yaitu sebagai alat untuk menyatakan perasaan dan buah pikiran kepada orang lain (Susanto 2012). Lain halnya menurut Smilansky yang menyatakan bahwa bahasa memiliki tiga fungsi bagi anak, yaitu: untuk meniru ucapan orang dewasa, membayangkan situasi (terutama dialog), dan mengatur permainan (Rachmawati and Kurniati 2010). Khotijah menambahkan empat fungsi bahasa sebagai berikut: sebagai alat untuk berkomunikasi dengan lingkungan; sebagai alat untuk mengembangkan kemampuan intelektual anak; sebagai alat untuk mengembangkan ekspresi anak; dan sebagai alat untuk menyatakan perasaan dan buah pikir kepada orang lain (Hastuti 2016).

Dengan karakteristik yang berbeda-beda, tentunya anak usia dini memiliki gaya belajar dan memerlukan media yang berbeda-beda dalam proses pembelajarannya. Menurut Priyatna, gaya belajar anak terdiri dari tiga gaya, yaitu pembelajar visual, pembelajar auditori, ataupun pembelajar kinestetik. Ia bahkan menambahkan adanya kombinasi dari tipe-tipe gaya belajar tersebut. Dengan mempertimbangkan tipe pembelajar yang bervariasi didalam kelas, maka diperlukan media pembelajaran yang mampu memfasilitasi berbagai 
kombinasi media gaya pembelajar tadi terutama dalam pengembangan kemampuan berbahasa anak (Priyatna 2013).

Zaman mengutip National Education Association (NEA) yang menyatakan bahwa media dalam mengembangkan kemampuan berbahasa anak usia dini dikatakan sebagai bentuk-bentuk komunikasi baik tercetak maupun dalam bentuk audio visual beserta peralatannya. Media hendaknya dapat dimanipulasi, dilihat, didengar dan dibaca (Badrul and Elliyawati 2010). Jadi dapat dikatakan bahwa media pembelajaran bahasa adalah suatu alat penyampaian pesan atau informasi yang berbentuk huruf dan kata-kata dan dapat disampaikan kepada anak dalam bentuk visual atau audio visual serta dapat dimanipulasi menurut kebutuhan dan perkembangan bahasa anak.

Dalam tulisan ini, penulis mengangkat media big book sebagai media pembelajaran bahasa. Sebagaimana yang di jelaskan oleh Hall \& Connor "big books typically use predictable texts, allowing readers to use their prior knowledge to identify words that come next in a sentence, as well as rhythm, rhyme, and repetition, all of which aid word recognition and identification" (ColvilleHall and O'Connor 2006). Fitriani dkk dalam Madyawati juga mengatakan big book adalah buku bergambar yang dipilih untuk dibesarkan yang memiliki karakteristik khusus, yaitu ada pembesaran baik teks maupun gambarnya (Madyawati 2016). Hal ini dilakukan agar terjadinya kegiatan membaca bersama (shared reading) antara guru, murid dan orang tua yang membawa dampak terhadap perkembangan Bahasa anak (Fielding-Barnsley 2007; Flack, Field, and Horst 2018; Levy, Hall, and Preece 2018). Buku ini mempunyai karakteristik khusus yang penuh warna-warni, gambar yang menarik, mempunyai kata yang dapat di ulang-ulang, mempunyai plot yang mudah di tebak, dan memiliki pola teks yang berirama untuk dapat dinyanyikan. Big book adalah buku berukuran besar dimana huruf cetak dan ilustrasi cukup besar bagi anak-anak untuk melihatnya ketika guru membacakan buku itu dalam kelompok. Dan big book digunakan untuk mengembangkan pengertian atau pemahaman anak-anak tentang konsep-konsep huruf cetak (Seefeldt and Wasik 2008).

Lynch mengemukakan terdapat beberapa keistimewaan media big book, diantaranya adalah : (a) Memberikan kesempatan kepada anak untuk terlibat dalam situasi nyata dengan cara yang tidak menakutkan, (b) Memungkinkan anak melihat tulisan yang sama ketika guru membaca tulisan tersebut, (c) Memungkinkan anak secara bersama-sama dengan bekerja sama memberi makna pada tulisan di dalamnya, (d) Memberikan kesempatan dan membantu anak yang mengalami keterlambatan membaca untuk mengenali tulisan dengan bantuan guru dan teman-teman lainnya, (e) Mengembangkan semua aspek bahasa termasuk kemampuan keaksaraan dan pengungkapan bahasa, (f) Dapat diselingi dengan percakapan yang relevan mengenai isi cerita bersama anak sehingga topik bacaan dan isi berkembang sesuai pengalaman dan imajinasi anak (Madyawati 2016).

Lynch juga memaparkan ciri-ciri dari sebuah big book yang baik, dimana isi sebuah cerita haruslah singkat (10-15 halaman), berisikan satu ide/topic cerita, memiliki pola kalimat yang jelas, memiliki gambar yang mengandung arti, font dan ukuran huruf dapat dibaca dengan jelas, dan memiliki alur cerita yang mudah dipahami (Lynch 2008).

Big book juga membantu anak untuk lebih fokus pada gambar dan teks. Sambil membaca cerita, pendidik dapat mendemontrasikan yang dibacanya dalam gambar dan menunjuk setiap kata yang dibaca. Dengan menggunakan big book, guru bisa menunjuk ke kata-kata ketika ia membaca dari kiri ke kanan, dan anak bisa membedakan banyak sosok huruf cetak, seperti kata-kata dan bukan gambar-gambar yang dibaca, bahwa kata-kata individu punya jarak masing-masing, dan bahwa kata-kata membentuk sebuah kalimat (Nalantha, Artini, and Mahayanti 2018; Ocbian et al. 2015; Seefeldt and Wasik 2008)

Penggunaan media belajar Big Book ini juga didukung oleh kemampuan guru dalam berkomunikasi. Sebagai seorang guru, pendidik di tuntut untuk mampu melakukan komunikasi secara demokratis dan menggunakan bentuk pertanyaan terbuka serta mampu menggunakan media-media kreatif dalam proses pembelajaran (Kementrian Pendidikan dan Kebudayaan 2018:8; Ocbian et al. 2015; Sitepu and Nasution 2018). Gaya komunikasi 
demokratis ini akan membantu anak dalam mengekspresikan dirinya melalui bahasa, terlebih dengan penggunaan bentuk pertanyaan yang mengajak anak untuk memberikan jawaban yang luas dan tidak terbatas pada jawaban ya atau tidak, atau jawaban singkat.

\section{METODOLOGI}

Penelitian ini menggunakan penelitian kualitatif dengan pendekatan penelitian tindakan kelas (PTK). Model pelaksanaan PTK yang dilakukan dalam penelitian ini adalah menggunakan model PTK kolaboratif, dimana peneliti melakukan kolaborasi dengan para kolaborator yang terdiri dari guru kelas, guru pendamping serta dua kolega penelitian. Pada saat penelitian, peneliti mengambil tempat sebagai pendidik di depan kelas. Sesuai dengan model PTK yang digunakan yaitu model Kurt Levin, peneliti beserta dengan tim kolaborator melakukan tahapan PTK, yaitu perencanaan, pelaksanaan, pengamatan dan refleksi (Dimyati 2013). Penelitian ini dilakukan dengan menggunakan dua (2) siklus. Berikut gambaran siklus yang dipakai dalam penelitian ini.

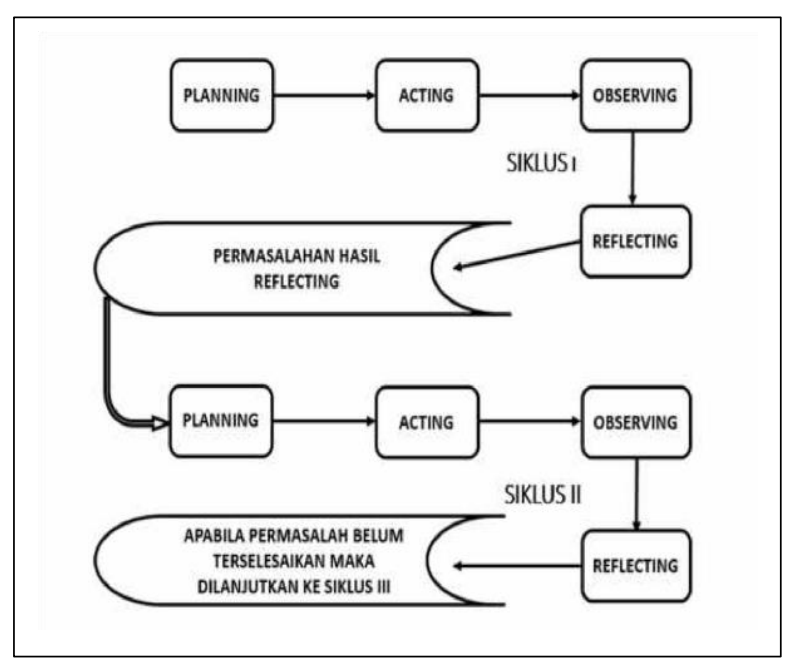

Gambar 1.1. Siklus I dan siklus II Kurt Lewin

Tahapan pelaksanaan penelitian dilakukan sebagai berikut: 1. Tahap perencanaan dimana peneliti melakukan: (a) mempersiapkan rencana pelaksanaan pembelajaran (RPP), (b) mempersiapkan media big Book sesuai tema, dan (c) mempersiapkan lembar observasi; 2. Tahap pelaksanaan, dimana peneliti: (a) menyampaikan cerita kepada anak dengan menggunakan big book, (b) menggunakan media big book untuk mengembangkan kemampuan berbahasa reseptif anak; 3. Tahap pengamatan, dimana tim kolaborator mengamati perkembangan berbahasa reseptif anak dengan menggunakan lembar pengamatan; dan, 4. Tahap refleksi, dimana peneliti dan tim kolaboratormerenungkan kembali serta melakukan tinjauan ulang terhadap keberhasilan dan kegagalan yang terjadi pada proses pembelajaran yang telah berlangsung. Apabila pada siklus I masih ada kekurangan atau kejanggalan dalam pelaksanaan pembelajaran, maka perlu dilanjutkan untuk perbaikan pada siklus II. Jika analisis menunjukkan peningkatan, maka siklus dapat di hentikan.

Subjek dalam penelitian ini adalah anak TK B usia 5-6 tahun di PAUD Ibnu Sina Beurabung Aceh Besar Kecamatan Darussalam Aceh Besar dengan jumlah 8 orang anak, yaitu 5 anak laki-laki dan 3 anak perempuan. Objek penelitian ini adalah kemampuan berbahasa anak reseptif pada anak usia 5-6 tahun dikelas TK B.

Instrumen penelitian yang digunakan berupa lembar observasi yang digunakan untuk mengukur kemampuan berbahasa reseptif anak selama penggunaan big book dan rubrik tanya jawab. Teknik analisis data dalam penelitian ini menggunakan teknik analisis deskriptif kualitatif. 
Tabel 1.1 Rubrik observasi kemampuan berbahasa reseptif anak

\begin{tabular}{|c|c|}
\hline No & Kemampuan Berbahasa Anak yang diukur \\
\hline 1 & Anak dapat memahami cerita yang disampaikan \\
\hline 2 & Anak dapat memahami aturan dalam kegiatan bercerita \\
\hline 3 & Anak dapat memahami kosa kata cerita yang di sampaikan \\
\hline 4 & $\begin{array}{l}\text { Anak dapat memahami kosa kata dengan } \\
\text { pengucapan. }\end{array}$ \\
\hline 5 & Anak mampu mengulang kosa kata yang disampaikan \\
\hline 6 & $\begin{array}{l}\text { Anak mampu menyimak cerita } \\
\text { yang di sampaikan }\end{array}$ \\
\hline 7 & $\begin{array}{l}\text { Anak mampu membedakan bentuk atau warna-warna benda dalam cerita } \\
\text { sesuai dengan nama-namanya. }\end{array}$ \\
\hline 8 & Anak mampu membedakan bahasa Aceh dan bahasa Indonesia dalam cerita \\
\hline 9 & Anak menghargai cerita yang telah disampaikan \\
\hline
\end{tabular}

Kemampuan berbahasa reseptif anak diukur dan dikategorikan dengan menggunakan kriteria Belum Berkembang (BB), Mulai Berkembang (MB), Berkembang Sesuai Harapan (BSH), dan Berkembang Sangat Baik (BSB). Hasil dari pengumpulan data observasi diatas kemudian akan diterjemahkan kedalam kategori persentase dengan menggunakan rumus persentase, yaitu:

$$
p=\frac{f}{n} \times 100 \%
$$

Keterangan:

$\mathrm{P}=$ Persentase

$\mathrm{F}=$ Frekuensi dari setiap jawaban angket

$\mathrm{N}=$ Jumlah skor ideal

100=Bilangan Tetap

(Anas Sudijono, 2005)

Kategori keberhasilan siklus akan menggunakan skor persentase $80 \%$ dalam kemampuan berbahasa reseptif anak dalam kriteria BSH dan BSB dengan perincian sebagai berikut:

Tabel 1.2. Kriteria Keberhasilan Kemampuan Berbahasa Reseptif Anak

\begin{tabular}{ll}
\hline Kriteria & \multicolumn{1}{c}{ Deskripsi } \\
\hline BB & Apabila anak berada pada kategori BSH dan BSB sebanyak 1-2 kali \\
MB & Apabila anak berada pada kategori BSH dan BSB sebanyak 3-5 kali \\
BSH & Apabila anak berada pada kategori BSH dan BSB sebanyak 6-7 kali \\
BSB & Apabila anak berada pada kategori BSH dan BSB sebanyak 8-9 kali \\
\hline
\end{tabular}

\section{HASIL DAN PEMBAHASAN}

\section{Siklus I}

Siklus pertama dilakukan oleh peneliti dan diobservasi oleh tim kolaborator. Pelaksanaan siklus 1 dengan memakai media big book dengan tema yang sudah disiapkan didalam tahapan perencanaan. Dalam siklus ini ditemukan tingkat kemampuan berbahasa ekspresif anak sebagai berikut: 
Tabel 1.3. Hasil observasi penilaian kemampuan berbahasa reseptif AUD dengan memakai media Big Book berdasarkan kriteria penilaian pada siklus I

\begin{tabular}{clcccc}
\hline No & $\begin{array}{l}\text { Kemampuan berbahasa reseptif AUD dengan memakai } \\
\text { media Big Book }\end{array}$ & BB & MB & BSH & BSB \\
\hline 1 & $\begin{array}{l}\text { Anak dapat memahami cerita yang di sampaikan } \\
2\end{array}$ & - & 2 & 6 & - \\
3 & $\begin{array}{l}\text { Anak dapat memahami aturan dalam kegiatan bercerita dapat memahami kosa kata cerita yang di } \\
\text { sampaikan }\end{array}$ & - & 4 & 3 & 1 \\
4 & $\begin{array}{l}\text { Anak dapat memahami kosa kata dengan pengucapan } \\
\text { Anak mampu mengulang kosa kata yang disampaikan }\end{array}$ & - & 4 & 3 & 1 \\
6 & $\begin{array}{l}\text { Anak mampu menyimak cerita yang disampaikan } \\
\text { Anak mampu membedakan bentuk atau warna-warna } \\
\text { benda dalam cerita sesuai dengan nama-namanya }\end{array}$ & - & 1 & 6 & 3 \\
8 & $\begin{array}{l}\text { Anak mampu membedakan bahasa aceh dan ahasa } \\
\text { indonesia dalam cerita }\end{array}$ & 1 & 4 & 2 & 1 \\
9 & Anak menghargai cerita yang telah di sampaikan & 1 & 4 & 3 & - \\
\hline
\end{tabular}

Dari data diatas ditemukan bahwa pada penilaian 1 sudah terdapat 6 orang anak yang mampu meraih kemampuan BSH dan 2 orang anak dengan kemampuan MB. Pada penilaian 2 terdapat 4 orang anak mencapai kemampuan MB, 2 orang anak dengan kemampuan BSH dan masing-masing 1 orang untuk kemampuan BSB dan BB. Penilaian 3 dan 4 memiliki jumlah anak yang sama untuk kemampuan MB dengan jumlah anak masingmasing sebanyak 4 orang, kemampuan BSH masing-masing sebanyak 3 orang dan kemampuan BSB masing-masing sebanyak 1 orang. Pada penilaian 5, kemampuan BSH dan BSB masing-masing mendapat kan jumlah 3 orang, kemampuan MB sebanyak 2 orang, sedangkan kemampuan BB kosong. Kemudian pada penilain 6, kemampuan BSH kembali mendapatkan jumlah anak terbanyak sebesar 6 orang, BSB seanyak 1 orang, MB sebanyak 1 orang, sedangkan BB kosong. Pada penilaian 7, 4 orang anak mendapatkan kemampuan BSH, sedangkan BSB hanya didapatkan oleh 1 orang anak, MB didapatkan oleh 2 orang anak dan BB oleh 1 orang anak. Penilaian 8 dan 9 memiliki kesamaan pda kemampuan MB dengan masing-masing jumlah anak sebanyak 4 orang. Sedangkan BSH didapatkan masingmasing 2 dan 3 orang anak. Kemampuan BSB hanya didapatkan oleh 1 orang anak pada penilaian 8 sedangkan kosong pada penilaian 9. Dan kemampuan BB sama-sama diraih oleh 1 orang anak untuk penilaian 8 dan 9 .

Penjelasan diatas menunjukkan bahwa kemampuan yang paling tinggi yang mampu di capai anak adalah BSH pada penilaian 1 dan 2, yang kemudian diikuti dengan penilaian 7 . Sedangkan kemampuan yang lain masih berada dibawah nilai rata-rata. Berikut adalah data sebaran kemampuan berbahasa reseptif per anak berdasarkan jumlah BSH dan BSB yang didapatnya pada siklus 1 :

Tabel 1.4. Frekuensi anak mencapai kemampuan BSH dan BSB

\begin{tabular}{ccc}
\hline No & Inisial anak & Kemampuan BSH dan BSB \\
\hline 1 & $\mathrm{Qa}$ & 6 \\
2 & $\mathrm{Hi}$ & 1 \\
3 & $\mathrm{Ri}$ & 9 \\
4 & $\mathrm{Aa}$ & 3 \\
5 & $\mathrm{In}$ & 6 \\
6 & $\mathrm{Ha}$ & 6 \\
7 & $\mathrm{Mn}$ & 3 \\
8 & $\mathrm{Nn}$ & 7 \\
\hline
\end{tabular}

Dari table diatas, dicarilah persentase untuk kriteria anak yang mendapatkan nilai BSH dan BSB untuk setiap penilaian untuk menentukan keberhasilan penelitian. 
Table 1.5. Persentase keberhasilan penelitian.pada siklus 1.

\begin{tabular}{ccc}
\hline kriteria & (F) & $(\mathbf{\%})$ \\
\hline BB & 1 & 12.5 \\
MB & 2 & 25 \\
BSH & 4 & 50 \\
BSB & 1 & 12.5 \\
\hline Jumlah anak BSH \& BSB & 5 & $62.5 \%$ \\
\hline
\end{tabular}

Tabel di atas menunjukkan anak yang memenuhi kriteria BSH \& BSB baru mencapai lima orang atau $62.5 \%$. Dan anak yang masih berada pada kriteria MB adalah dua anak atau $25 \%$ dan yang berada pada kriteria BB adalah satu anak atau $12.5 \%$.

\section{Siklus II}

Siklus II juga dilaksanakan oleh peneliti bekerjasama dengan tim kolaborator. Pelaksanaan siklus II dilakukan dengan mengikuti tahapan perencanaan setelah dilakukannya refleksi pada siklus I.

Tabel 1.6. Hasil observasi penilaian kemampuan berbahasa reseptif AUD dengan memakai media Big Book berdasarkan kriteria penilaian pada siklus II

\begin{tabular}{llcccc}
\hline No & $\begin{array}{l}\text { Kemampuan berbahasa reseptif AUD dengan memakai } \\
\text { media Big Book }\end{array}$ & BB & MB & BSH & BSB \\
\hline 1 & Anak dapat memahami cerita yang di sampaikan & - & 1 & 2 & 5 \\
2 & Anak dapat memahami aturan dalam kegiatan bercerita & - & 4 & 1 & 3 \\
3 & Anak dapat memahami kosa kata cerita yang di sampaikan & - & 2 & 4 & 2 \\
4 & Anak dapat memahami kosa kata dengan pengucapan & - & - & 4 & 4 \\
5 & Anak mampu mengulang kosa kata yang disampaikan & - & - & 5 & 3 \\
6 & Anak mampu menyimak cerita yang disampaikan & - & - & 2 & 6 \\
7 & $\begin{array}{l}\text { Anak mampu membedakan bentuk atau warna-warna benda } \\
\text { dalam cerita sesuai dengan nama-namanya }\end{array}$ & - & 2 & 2 & 4 \\
8 & $\begin{array}{l}\text { Anak mampu membedakan bahasa aceh dan ahasa indonesia } \\
\text { dalam cerita }\end{array}$ & - & 1 & 5 & 2 \\
9 & Anak menghargai cerita yang telah di sampaikan & - & 2 & 4 & 2 \\
\hline
\end{tabular}

Dari data diatas didapati terjadinya peningkatan kemampuan pada anak dimulai pada penilaian 1 dengan tercapainya kemampuan BSB sebanyak 5 orang anak, yang diikuti dengan kemampuan BSH sebanyak 2 orang dan kemampuan MB sebanyak 1 orang. Pada penilaian 2, kemampuan BSB diraih oleh 3 orang anak, kemampuan BSH diraih oleh 1 orang anak dan 4 orang masih berada pada kemampuan MB. Penilaian 3 memperlihatkan kemampuan BSB diraih oleh 2 orang anak, kemampuan BSH diraih 4 orang anak dan kemampuan MB diraih oleh 2 orang anak. Pada penilaian 4 kemampuan BSH dan BSB samasama diraih oleh masing-masing 4 orang anak. Pada poin penilaian 5, kemampuan BSB dicapai oleh 3 orang anak dan kemampuan BSH diraih oleh 5 orang anak. Poin penilaian 6 memperlihatkan kemampuan BSB diraih oleh 6 orang anak dan kemampuan BSH diraih oleh 2 orang anak. Kemudian pada penilaian 7, kemampuan BSB dicapai oleh 4 orang anak, kemampuan BSH diraih 2 orang anak dan kemampuan MB diraih oleh 2 orang anak. Poin penilaian 8 memperlihatkan kemampuan BSB diraih oleh 2 orang anak, kemampuan BSH dirah oleh 5 orang anak dan kemampuan MB diraih oleh 1 orang anak. Penilaian 9 memperlihatkan kemampuan BSB anak hanya dirah oleh 2 orang anak, kemampuan BSH diraih oleh 4 orang anak dan kemampuan MB diraih oleh 2 orang anak. 
Penjelasan diatas menunjukkan peningkatan kemampuan anak dimana terjadi pergeseran kemampuan dari BSH ke BSB, dari MB ke BSH, dan sudah tidak ada anak yang berada pada kemampuan BB.

Berikut adalah data sebaran kemampuan berbahasa reseptif per anak berdasarkan jumlah BSH dan BSB yang didapatnya pada siklus II:

Tabel 1.7. Frekuensi anak mencapai kemampuan BSH dan BSB

\begin{tabular}{ccc}
\hline No & Inisial anak & Kemampuan BSH dan BSB \\
\hline 1 & Qa & 8 \\
2 & $\mathrm{Hi}$ & 5 \\
3 & $\mathrm{Ri}$ & 9 \\
4 & $\mathrm{Aa}$ & 7 \\
5 & $\mathrm{In}$ & 8 \\
6 & $\mathrm{Ha}$ & 7 \\
7 & $\mathrm{Mn}$ & 8 \\
8 & $\mathrm{Nn}$ & \\
\hline
\end{tabular}

Dari tabel diatas, dicarilah persentase untuk kriteria anak yang mendapatkan nilai BSH dan BSB untuk setiap penilaian untuk menentukan keberhasilan penelitian.

Table 1.8. Persentase keberhasilan penelitian.pada siklus II.

\begin{tabular}{ccc}
\hline kriteria & (F) & $\mathbf{( \% )}$ \\
\hline BB & - & - \\
MB & 1 & 12.5 \\
BSH & 2 & 25 \\
BSB & 5 & 62.5 \\
\hline Jumlah anak BSH \& BSB & 7 & $87.5 \%$ \\
\hline
\end{tabular}

Dari tabel di atas di temukan bahwa anak yang memenuhi kriteria BSH \& BSB sebanyak tujuh atau $87.5 \%$. Anak yang masih memenuhi kriteria MB adalah satu anak atau $12.5 \%$ dan tidak ada lagi anak yang memenuhi kriteria BB. Pada siklus II ini, terlihat peningkatan jumlah anak yang mampu memberikan jawaban yang luas sesuai dengan pertanyaan-pertanyaan yang diberikan oleh guru.

Kemampuan berbahasa reseptif anak dengan menggunakan media big book pada siklus I dan siklus II disajikan dalam diagram batang sebagai berikut.

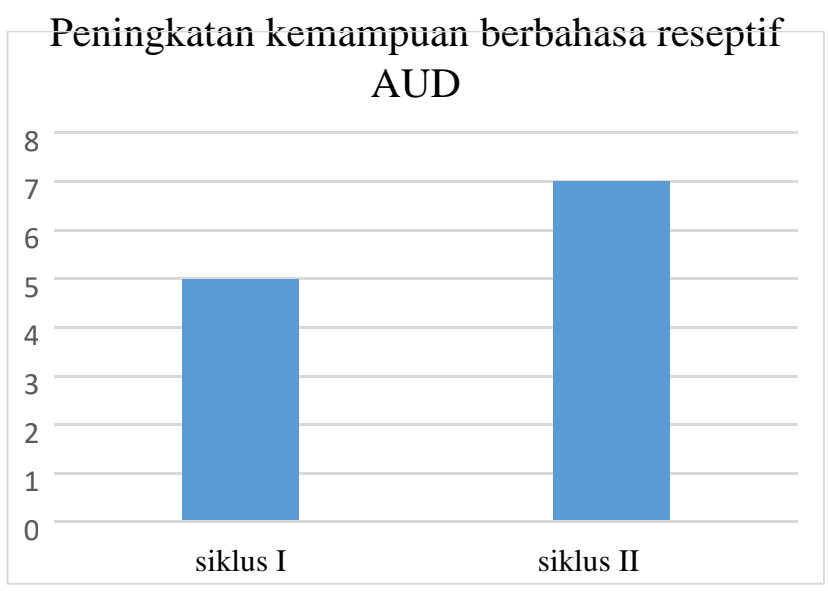

Diagram 1. 1. Kemampuan berbahasa reseptif AUD dengan menggunakan media Big Book pada siklus I dan siklus II. 


\section{SIMPULAN}

Penelitian ini dilakukan dalam waktu dua siklus. Penentuan keberhasilannya ditetapkan berdasarkan perkembangan kemampuan berbahasa reseptif anaak yang mencapai $80 \%$ dengan kemampuan anak berada pada Berkembang Sesuai Harapan (BSH) dan Berkembang Sangat Baik (BSB). Perkembangan kemampuan berbahasa reseptif anak berkembang dari siklus pertama hingga ke siklus kedua dengan nilai persentase 62,5\% menjadi $87,5 \%$. Penggunaan media belajar big book berupa huruf yang dibesarkan, gambar yang menarik serta kosakata yang sering ditemui oleh anak mampu menarik perhatian anak sehingga anak melakukan kegiatan menyimak pada saat proses pembelajaran.hal ini tentunya tanpa terlepas dari penggunaan gaya komunikasi guru dan model pertanyaan yang digunakan.

\section{UCAPAN TERIMAKASIH}

Ucapan Terima Kasih diberikan kepada Program Studi Pendidikan Islam Anak usia Dini, UIN Ar Raniry dan TK Dharma Wanita Teunom, Aceh Jaya. Serta tempat dilaksanakannya penelitian ini, yaitu di PAUD Ibnu Sina. Tak lupa juga kepada seluruh pihak yang terlibat dalam pelaksanaan penelitian ini.

\section{DAFTAR PUSTAKA}

Adini, Alfira Luluk. 2016. "Kemampuan Bahasa Reseptif Anak Kelompok A Gugus V Kecamatan Berbah." Jurnal Pendidikan Anak Usia Dini 5(6):600-611.

Badrul, Zaman and Cucu Elliyawati. 2010. Media Pembelajaran Anak Usia DIni. Unpublished.

Colville-Hall, Susan and Barbara O'Connor. 2006. "Using Big Books: A Standards-Based Instructional Approach for Foreign Language Teacher Candidates in a PreK-12 Program." Foreign Language Annals 39(3):487-506. https://doi.org/10.1111/j.19449720.2006.tb02901.x.

Dhieni et al, Nurbiana. 2014. Metode Pengembangan Bahasa: Buku Materi Pokok PAUD 4106. Vol. Modul 1-12. 1st ed. Universitas Terbuka.

Dimyati, Johni. 2013. Metode Penelitian Pendidikan Dan Aplikasinya Pada Pendidikan Anak Usia Dini (PAUD). Jakarta: Kencana.

Fielding-Barnsley, Ruth. 2007. “Facilitating Children's Emergent Literacy Using Shared Reading: A Comparison of Two Models." Australian Journal of Language and Literacy 30:191-202.

Flack, Zoe M., Andy P. Field, and Jessica S. Horst. 2018. “The Effects of Shared Storybook Reading on Word Learning: A Meta-Analysis." Developmental Psychology 54(7):1334-46. https:// doi.org/10.1037/dev0000512.

Hastuti, Dwi. 2016. "Strategi Pengembangan Harga Diri Anak Usia Dini." JURNAL JPSD (Jurnal Pendidikan Sekolah Dasar) 2(2):38. https:// doi.org/10.26555/jpsd.v2i2.a5486.

Kementrian Pendidikan dan Kebudayaan. 2018. Modul 8: Komunikasi Dalam Pengasuhan. Vol. Modul 8. Jakarta: Kemdikbud.

Khairin, Friska Nisa. 2012. "Pengaruh Terapi Musik Mozart dalam Meningkatkan Kemampuan Bahasa Reseptif dan Ekspresif pada Anak Autistik di SLB BC Pambudi Dharma 1 Cimahi." other, Universitas Pendidikan Indonesia.

Levy, Rachael, Melanie Hall, and Jenny Preece. 2018. "Examining the Links between Parents' Relationships with Reading and Shared Reading with Their Pre-School Children." International Journal of Educational Psychology 7(2):123.

Lynch, Priscilla. 2008. Using Big Books and Predictable Books. Canada: Scholastic Canada Ltd.

Madyawati, Lilis. 2016. Strategi Pengembangan Bahasa Pada Anak. Jakarta: Kencana.

Nalantha, IMD, LP Artini, and NWS Mahayanti. 2018. "The Effect of Big Books as Teaching Media on The Third Grade Students' Reading Comprehension in South Bali." International Journal of Language and Literature 2(2). 
https://doi.org/10.23887/ijll.v2i2.16096.

Ocbian, Magdalena M., Mary Anne F. Suod, Jhonson G. Garduque Jr, and Leny F. Bringino. 2015. "Acceptability of Big Books as Mother Tongue-Based Reading Materials in Bulusan Dialect." Asia Pacific Journal of Multidisciplinary Research 3(4.4):17-23.

Permendikbud. 2014. Standar Nasional PAUD.

Priyatna, Andri. 2013. Pahami Gaya Belajar Anak: Memaksimalkan Potensi Anak Dengan Modifikasi Gaya Belajar. Jakarta: PT Elex Media Komputindo.

Rachmawati, Yeni and Euis Kurniati. 2010. Strategei Pengembangan Kreativitas Pada Anak Usia Dini. Jakarta: Kencana.

Seefeldt, Carol and Barbara A. Wasik. 2008. Pendidikan Anak Usia Dini: Menyiapkan Anak Usia 3, 4, Dan 5 Tahun Masuk Sekolah. 2nd ed. Jakarta: Indeks.

Sitepu, Juli Maini and Mawaddah Nasution. 2018. "Kreativitas Pembuatan Media Pembelajaran Big Book Pada Guru-Guru RA Di Kecamatan Medan Maimun." Jurnal Prodikmas Hasil Pengabdian Kepada Masyarakat 3(1).

Susanto, Ahmad. 2012. Perkembangan Anak Usia Dini: Pengantar Dalam Berbagai Aspeknya. Jakarta: Kencana. 